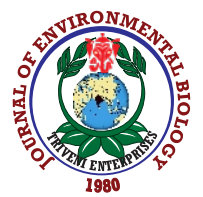

\title{
Haematological and histoarchitectural alterations in Cyprinus carpio (Linnaeus 1758) fed with Sesbania leaf meal
}

\author{
G. Anand, P.P. Srivastava*, T. Varghese, N.P. Sahu, M. Xavier, V. Harikriskna, A. Prabhakaran and P. Kumari \\ 'ICAR-Central Institute of Fisheries Education, Mumbai-400 061, India \\ *Corresponding Author Email : ppsrivastava@cife.edu.in
}

\section{Abstract}

Aim: To determine the effect of feeding Sesbania leaf meal (SLM) in the diet of Cyprinus carpio (Common carp) in replacement of de-oiled rice bran (DORB)

Methodology: A60-day-feeding trial was conducted by feeding common carp with diets containing $15 \%$ to $30 \%$ Sesbania leaf meal replacing DORB. Liver and intestine tissues were collected for histological examination, while blood was collected for estimation of blood count and serum metabolites (glucose, white blood cell (WBC), red blood cell (RBC), packed cell volume (PCV) and haemoglobin).

Results: Serum glucose value was significantly $(P<0.05)$ higher in the leaf meal fed groups compared to the control group. RBC and PCV value were highest in control group while WBC values were lower in the control group. Intestine and liver histology showed pathological alterations in Sesbania leaf meal fed groups compared to the control group.

Interpretation: The study indicated that raw Sesbania leaf meal had an obvious adverse effect on the health of Cyprinus carpio fingerlings. The mortalities observed due to leaf meal inclusion indicate their intolerance to the toxic factors present in the Sesbania leaf meal.

Key words: Cyprinus carpio, Histology, Sesbania leaf meal, Serum parameters

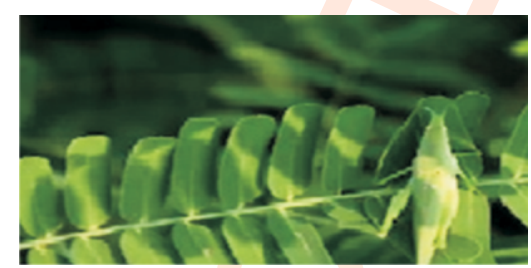

Sesbania leaf meal

Survival - \%

DORB - 100\%

Sesbania leaf meal $-60 \%$
Fed to C. carpio
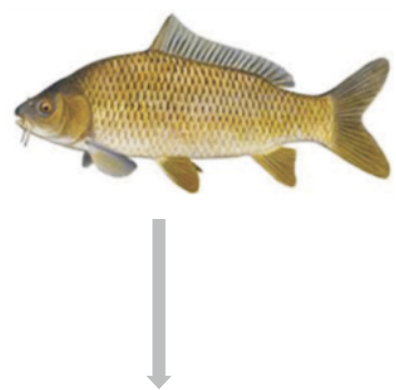

Effect on histological alteration, blood parameters

How to cite : Anand, G., P.P. Srivastava, T. Varghese, N.P. Sahu, M. Xavier, V. Harikriskna, A. Prabhakaran and P. Kumari: Haematological and histoarchitectural alterations in Cyprinus carpio (Linnaeus 1758) fed with Sesbania leaf meal. J. Environ. Biol., 41, 1082-1088 (2020). 


\section{Introduction}

Aquafeed industry is heavily dependent on deoiled rice bran (DORB) as major ingredient. However, other animal feed industries are equally in demand for rice bran, which may reduce the availability of DORB for aquafeed in near future. Thus, there is a need to search for other plant ingredients as alternative sources to fulfil the increasing demand for aquafeed industry as animal sources are expensive and less available for the manufacture of fish feed (El-Sayed, 1999; Francis et al., 2012). Till date, several studies have been conducted on different parts of various plant species which has been used as an alternative available protein source for aquafeed without compromising the nutritional quality of the aquafeed. Leaves of many plants such as Medicago sativa, Leucaena leucocephala, Moringa oleifera, sweet potato, Morus esculenta, Manihot esculenta and Hygrophila spinosa (Ali et al.,2003; Bairagi et al., 2004; Diarra et al., 2017; Meshram et al., 2018; Mondal et al., 2012; Maiti et al., 2019) have been incorporated in fish diets. However, at the same time, the significant constraints in the use of alternative plant ingredients were observed, especially negative impact on growth performance, digestibility and health status. (Kumar et al., 2010; Hemre et al., 2009; Hardy, 2010; Hansen and Hemre, 2013; Wang et al. 2016). In this context, the present study aimed to evaluate Sesbania leaf meal in aquafeeds, which is considered as a valuable plant in tropical agriculture (Sileshi et al., 2003). They belong to family fabaceae and are grown in agricultural fields because of their ability for nitrogen fixation (Kareem and Sundararaj,1967; Wood and Larkens,1987). They are also used as fodder and green manure due to their high protein and low fibre content (Onim et al., 1987; Panda et al., 1988). Six species of genus Sesbania is distributed throughout India. Among them, Sesbania aculeata, which is commonly known as dhaincha, was selected for the study. Previously, some studies are available on Sesbania aculeata seed meal as a dietary protein source for common carp (Hossain et al., 2001) and tilapia (Hossain et al., 2002) diets.

As no study has been conducted on the incorporation of Sesbania leaf meal as an aquafeed ingredient till date, the present study undertook a feeding trial of common carp. Scaled variety of common carp, Cyprinus carpio var. communis was selected for the study due to its exceptionally high growth rate, easy availability, broad distribution and commercial importance (Mohapatra and Patra, 2013). Common carp, being an omnivorous species expected to have an ability for utilisation of unconventional plant protein sources. Haematological and histopathological analysis was performed to understand the effect of feeding Sesbania leafmeal on their health status. Nowadays, fish haematological studies are gaining importance because of their role in monitoring the health status of fishes (Hrubec et al., 2000). Haematological characteristics have been studied in most fishes with the aim of establishing a reasonable value range and in case any variation from it may be considered as an indicator for disturbances in their physiological process (Rainza-paiva et al., 2000). Similarly, the histopathological studies will give a clear picture of the extent of tissue damage due to the presence of antinutritional factors in the plant sources. Thus, the present study aimed at evaluating Sesbania leafmeal as a replacer of the most common ingredient, DORB owing to its nutritional composition similar to the leaf meals with high fibre, low cost, presence of antinutritional factors and protein content below $30 \%$.

\section{Materials and Methods}

Collection and processing of sesbania leaves: Sesbania leaves were collected from Samastipur district of Bihar, India. The collected leaf was washed thoroughly in order to remove dirt particles. After washing, the leaves were sun dried for two days. Further, the leaves were oven dried at $60^{\circ} \mathrm{C}$ for reducing the moisture content below $10 \%$. Dried leaf was powdered and sieved through $40 \mu$ mesh.

Analysis of antinutritional factors from Sesbania leaves : Antinutrients present in sesbania leaves were analysed following the standard methods. Saponin content of leaf was determined by the method of Hiai et al. (1976). Phytic acid was determined according to the colorimetric assay described by Gao et al. (2007). Total tannin content was estimated using spectrophotometric method as described by Makkar et al. (2007).

Diet preparation : Three different isonitrogenous and isoenergetic diets were prepared with $30 \%$ crude protein and $6.0 \%$ lipid respectively (Table 1 ). The maximum content of Sesbania leaf meal inclusion was decided to be $30 \%$. As leaf meal was used as a rice bran replacer, this was selected depending upon the inclusion of DORB used in the aquafeed, which was also reported to be 30\% (Kumar et al., 2018). As 30\% inclusion of leafmeal instead of DORB becomes $100 \%$ replacement, $50 \%$ replacement level was also selected (15\% inclusion) to make another feed. Lower levels were not selected as it was meaningless to incorporate any cheap ingredient below $15 \%$, considering the energy spent for its collection and processing. Three diets were designated as T1 (control diet with 0\% SLM), T2 (15\% SLM) and T3 (30\% SLM). Prior to processing, all the feed ingredients including Sesbania leaf meal, were ground individually, independently weighed and mixed properly by adding sufficient water. The dough, thus made was subjected to palletisation through a die of size $2.5 \mathrm{~mm}$ and prepared noodlelike strands were cut into small pieces and dried properly. Diets prepared were subjected to proximate analysis by following the standards of AOAC (1995).

Experimental setup : The present study was conducted at the Wet Laboratory of Central Institute of Fisheries Education, Rohtak, India. Two hundred and twenty-five juveniles of common carp with the average weight of $15.9 \pm 0.05 \mathrm{~g}$ were purchased from sampla village of Haryana. Fishes were acclimatised for 
Table 1: Composition of different experimental diets (\% dry matter)

\begin{tabular}{llll}
\hline Ingredients & C (0\% SLM) & SLM $15 \%$ & SLM 30\% \\
\hline DSBM & 40 & 40 & 40 \\
GNOC & 21 & 15.6 & 10 \\
Wheatflour & 1.70 & 7.20 & 13 \\
DORB & 30 & 15 & 0 \\
SLM & 0 & 15 & 30 \\
Vit-min mix & 1.20 & 1.2 & 1.2 \\
Choline chloride & 0.20 & 0.20 & 0.20 \\
CMC & 1.50 & 1.5 & 1.5 \\
BHT & 0.1 & 0.1 & 0.1 \\
Oil & 4.3 & 4.2 & 4.0 \\
Proximate composition of feed (\%) & & \\
Moisture & 8.92 & 9.01 & 9.05 \\
Crude protein & 32.83 & 33.02 & 33.29 \\
Ether extract & 5.92 & 6.04 & 5.80 \\
Toatal ash & 7.02 & 7.20 & 7.10 \\
Crude fibre & 7.54 & 7.14 & 6.81 \\
NFE & 46.69 & 46.60 & 47.00 \\
Dry matter & 91.08 & 90.99 & 90.95 \\
\hline
\end{tabular}

*Oil-sunflower :fish-1:1. Note. BHT, butylated hydroxytoluene; CMC, carboxymethyl cellulose; DORB, de-oiled rice bran; DSBM, defatted soybean meal; GNOC, groundnut oil cake; NFE, nitrogen-free extract.(NFE = 100-(CP + CL + CF + ash); SLM, Sesbania leaf meal; vitamin mineral mix (PRE-EMIX PLUS) (quantity $/ \mathrm{kg}$ ) -Vitamin A- 5500,000 IU; Vitamin D-1 $100000 \mathrm{IU}$; Vitamin B2-2000 mg; Vitamin E- 750 mg; Vitamin K-1000 mg; Vitamin B- 1000 mg; Vitamin $\mathrm{B}_{12}-6 \mathrm{mcg}$; Calcium Pantothenate-2,500 mg; Nicotinamide- $10 \mathrm{~g}$; Choline Chloride-150 g; Mn- $27000 \mathrm{mg} ; \mathrm{I}-1000 \mathrm{mg} ; \mathrm{Fe}-7500 \mathrm{mg} ; \mathrm{Zn}-$ 5000 mg; Cu- 2000 mg; Co- 450 mg; L-lysine- 10 g; DL- Methionine-10 g; Selenium-50ppm

twenty days and were randomly distributed in circular FRP tanks of $500 \mathrm{I}$ capacity at a stocking density of 15 fishes in each tank in triplicates. Fishes were fed twice a day at 8:00 and 18:00 hrs. During the acclimation period, fishes were fed with control diet $(0 \%$ SLM). All the physico-chemical parameters of water were maintained throughout the experimental period as per the requirement of common carp.

Collection of blood and haematological analysis : After 60 days of feeding trial sampling was performed by following all the ethical guidelines of the animal cares for ICAR-Central Institute of Fisheries Education, Mumbai India. Fishes were anaesthetised before blood collection using clove oil $\left(50 \mu \mathrm{I} \mathrm{I}^{-1}\right)$ Medical syringe (No 23) was used for puncturing the caudal vein which was previously rinsed with $2.7 \%$ EDTA for blood collection. The collected blood sample was used for haematological analysis (RBC, Hemoglobin, WBC, PCV). The haemoglobin level of blood was analysed following the Cyanmethemoglobin method using Drabkins Fluid (Qualigens, Mumbai, India). Blood (20 $\mu$ l) was mixed with $5 \mathrm{ml}$ of Drabkin's working solution. The absorbance was read on a spectrophotometer at $540 \mathrm{~nm}$. The final concentration was calculated by comparing with the standard cyanmethemoglobin (Qualigens Diagnostics). Haematocrit value (PCV) was determined by drawing non-dotted blood by capillary action into microhaematocrit tubes. One end of the tubes was sealed with synthetic sealant. The sealed tube was centrifuged in a microhaemotocrit centrifuge for $5 \mathrm{~min}$ at $10,500 \mathrm{rpm}$ and the values were recorded in microhaemotocrit as percentage. WBC and RBC count was performed by using leucocytes and erythrocytes diluting fluids respectively (Qualigens). Blood (20 $\mu$ l) was mixed with $3980 \mu$ l of RBC diluting fluid in a clean test tube. The mixture was shaken well to suspend the cells uniformly in the solution. A small drop of this mixture was charged to Neubauer's counting chamber of haemocytometer. The following formula was used to calculate the leucocytes and erythrocytes per $\mathrm{ml}$ of the blood samples: No. of cells/ml= (No. of cells counted $\times$ dilution)/ (Area counted $\times$ depth of fluid).

Serum samples were collected without using EDTA and these samples were allowed to clot for $2 \mathrm{hr}$ then centrifuged ( 5000 $\mathrm{g}$ for $5 \mathrm{~min}$ at $\left.4^{\circ} \mathrm{C}\right)$. Serum glucose was analysed by commercial kit (Erba®Diagnostic Mannheim, Transasia Biomedicals Ltd, Solan, HP, India) following the manufacturers' instructions, based on the glucose oxidase-peroxidase method.

Histological studies of liver and intestine : After 60 days of feeding trial, liver and intestine sample of each experimental groups ( 3 each) were dissected and were instantly fixed in neutrally buffered formalin (NBF) and embedded using paraffin wax. Tissue blocks, thus prepared were sectioned at $5 \mathrm{~mm}$ thickness with the help of microtome, and they were collected on glass slides. The sections were exposed hydration and dehydration cycles using varying concentrations of alcohol solution. The slides were then dewaxed using xylene and stained 
with haematoxylin and eosin following the method of Roberts (1989). Tissue sections were examined under light microscopy and mounted with a coverslip. The photos were taken at different magnification (20X and 40X) and selected the appropriate ones under light microscope.

\section{Results and Discussion}

In the present study, the highest survival was recorded in $\mathrm{T} 1$ (control) group, and the lowest was observed in T3 (R30\%) followed by T2 (R15\%) SLM fed groups. The survival percentage was reduced drastically with the inclusion of Sesbania leaf meal. The toxicity of leaf meal could explain this mortality. Our study is supported by the report of Brown et al. (1987) and Shequeir et al. (1989) in which high mortality, low feed intake and growth depression were found when chicks were fed with $S$. sesban. This may be due to the presence of toxic compounds like saponin, tannin, amines and alkaloid sesbanine (Bell,1978; Kinghorn and Smolenski,1978). The analysis of antinutritional factors in the present study revealed that the saponin, phytic acid and tannin contents in Seasbania leaf meal was 18.12 $\pm 0.81,16.20 \pm 1.20$ and $14.10 \pm 1.01 \mathrm{~g} \mathrm{~kg}^{-1}$, respectively.

In the present study, haematological and histopathological changes were observed after feeding Cyprinus carpio fingerlings with the feed containing Sesbania leaf meal in comparison to the control group fed without any leaf meal (Table 2). Similarly, Brown et al. (1987) and Shqueir et al. (1989) observed decrease in growth performance, low feed intake as well as mortality in growing broiler when they were fed with Sesbania sesban leaf meal. Haematological parameters are generally considered as important indicators for the evaluation of fish health (Gabriel et al., 2004). The previous study conducted by Osuigwe et al. (2005) revealed that haematological parameters in fishes vary due several factors such as size, age, physiological status, environmental conditions as well as dietary regime. Blood profiles can be used to evaluate the physiological responses of fish. Stress responses in animals can be observed from the changes of cortisol, blood glucose, haemoglobin, and hematocrit levels. In the present study, RBC and PCV values decreased significantly $(P<0.05)$ with increasing the quantity of Sesbania leaf meal in the diet and the highest value was observed in the control group. The $P C V$ value in the blood decreased due to the presence of toxic factors which showed an adverse effect on blood formation
(Oyawoye and Ogunkunle, 1998). However, a decrease in RBC value with the inclusion of Sesbania leaf meal was due to the presence of antinutritional factors such as tannin, saponin and alkaloids (Bell,1978; Kinghorn and Smolenski,1978).

Similarly, Bello et al. (2013) found a reduction in RBC count when fishes were fed with $M$. oleifera leaf meal-based diet. Douglass and Janes (2010) stated that the amount of WBC in blood have an implication in immune responses and the ability of animal to fight against the existing infection. In the present study, WBC count increased with inclusion of leaf meal as compared to the control group. This may be due to the feed toxicity caused by ANFs in Sesbania leaf meal. According to Oyawoye and Ogunkunle (1998), elevated WBC count is usually related to microbial infection or the presence of a foreign body or antigen in the circulating system. In the present study, blood glucose showed an increasing trend with increasing inclusion level of Sesbania leaf meal in the diet of Cyprinus carpio. According to Varghese et al. (2019), elevated blood glucose level is an indicator of stress due to metabolic alterations in carp exposed to hypoxia. However, Sesbania seed meal did not cause any metabolic stress in tilapia (Hossain et al., 2002) which may be due to lower antinutrient content in the seeds as compared to leaves.

Intestine histology in C. carpio showed pathological alterations in Sesbania leaf meal fed groups compared to control groups (Fig. 1). Shorter villi and reduced length of intestinal fold were observed when fed with $15 \%$ and $30 \%$ SLM containing feed compared to the control group (DORB). The longer villi found in the intestine of control group indicates higher efficiency in the absorptive process resulting in better growth and production ( $\mathrm{Da}$ Silva et al., 2012; Caballero et al., 2003). Furthermore, the enterocytes of these fish intestine showed an increase in the number of goblet cells and microvilli degeneration. The widening of central stroma, with high infiltration of inflammatory cells in the lamina propria and epithelium, were more evident in the group fed with $30 \%$ SLM compared to $15 \%$ SLM fed groups. The reduction in villi height results in reduced surface area for nutrient absorption (Da Silva et al., 2012).

Furthermore, the intestinal histology revealed an increase in goblet cell number and microvilli degeneration with increase in the inclusion of SLM in the diet. The increase in the number of goblet cells may be an indication of increased irritation of brush border lining leading to more mucus production. This mucus serves as a lubricant providing protection against chemical and

Table 2 : Haematological paramters of Cyprinus carpio fed with Sesbania leaf meal based diet after 60 days of experiment

\begin{tabular}{llllll}
\hline Treatments & $\mathrm{PCV}(\%)$ & $\mathrm{RBC}\left(10^{6}\right.$ cells $\left.\mathrm{m}^{-3}\right)$ & $\mathrm{Hb}\left(\mathrm{g} \mathrm{dl}^{-1}\right)$ & WBC $\left(10^{3}\right.$ cells $\left.\mathrm{mm}^{-3}\right)$ & Glucose $\left(\mathrm{mg} \mathrm{dl}^{-1}\right)$ \\
\hline $\mathrm{T} 1($ Control $)$ & $21.18^{\mathrm{b}} \pm 0.83$ & $2.03^{\mathrm{b}} \pm 0.08$ & $8.07 \pm 0.33$ & $124.13^{\mathrm{a}} \pm 5.37$ & $36.26^{\mathrm{a}} \pm 2.25$ \\
$\mathrm{~T} 1(15 \% \mathrm{R})$ & $19.38^{\mathrm{ab}} \pm 0.52$ & $1.76^{\mathrm{a}} \pm 0.04$ & $7.83 \pm 0.22$ & $181.32^{\mathrm{b}} \pm 9.05$ & $41.32^{\mathrm{ab}} \pm 1.88$ \\
$\mathrm{~T} 2(30 \% \mathrm{R})$ & $18.27^{\mathrm{a}} \pm 0.48$ & $1.57^{\mathrm{a}} \pm 0.07$ & $7.5 \pm 0.23$ & $221.36^{\mathrm{c}} \pm 8.85$ & $44.47^{\mathrm{b}} \pm 1.68$ \\
p-value & 0.045 & 0.009 & 0.372 & 0.001 & 0.064 \\
\hline
\end{tabular}

Values are mean of six replicates $\pm S E$. Values in the same column with different superscripts are significantly $(P<0.05)$ different, $n=6$. $P C V$, packed cell volume; RBC, red blood cell, Hb, haemoglobulin; WBC, white blood cell 
mechanical damage. The increase in goblet cell number may also be an immune response against anti-nutrients as reported by Marchetti et al. (2006). Further, saponin was present in the SLM which may have surface-active constituents that may damage biological membranes resulting in increased permeability of mucosal cells (Bureau et al., 1998). Higher saponin concentrations in $30 \%$ SLM may explain the negative effect of this
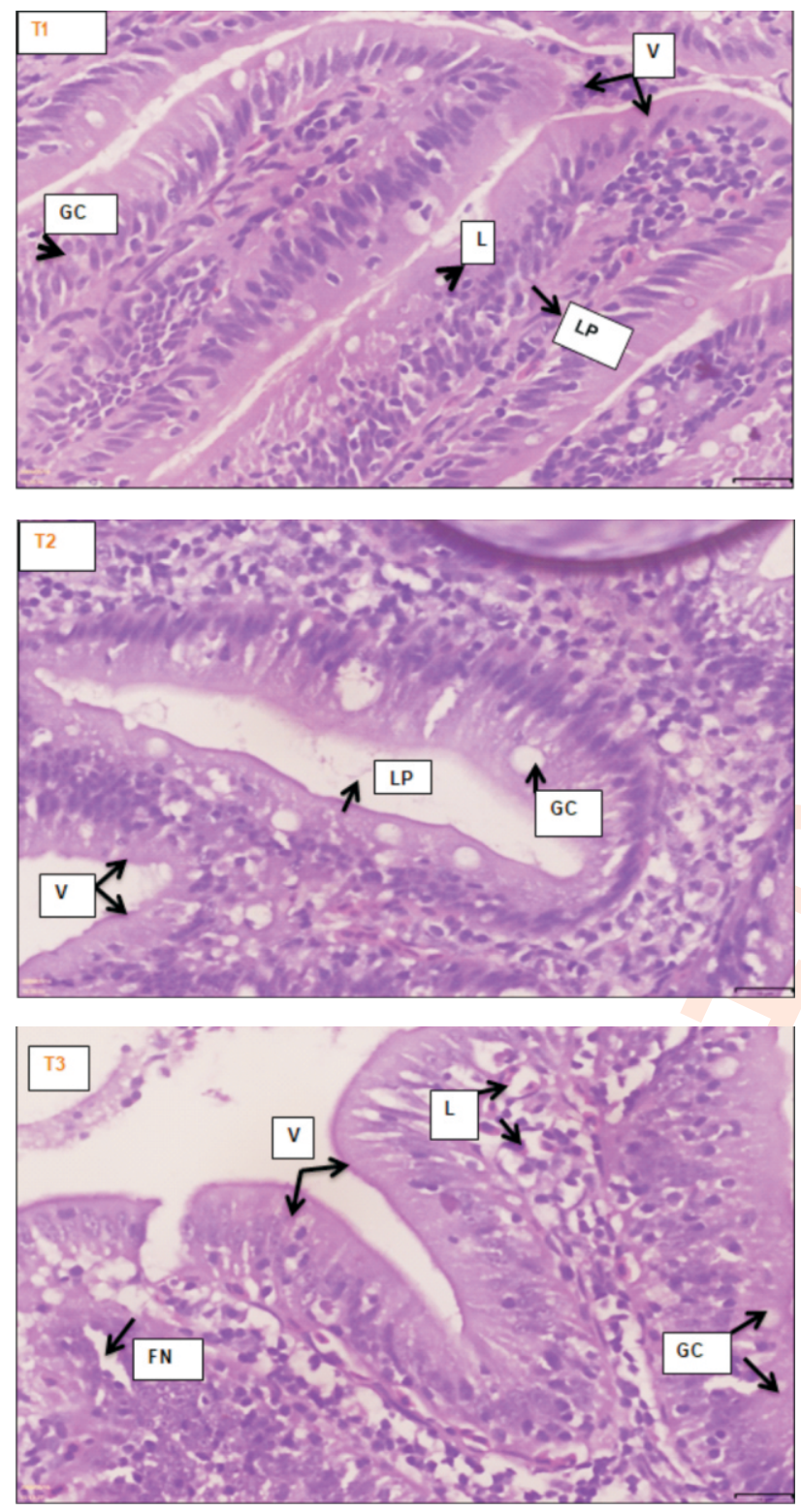

Fig. 1 : Intestine of experimental fish (C. carpio) fed feed. T1- Fed with $0 \%$ SLM showing normal architecture; T2- Fed with 15\% SLM shows increased number of goblet cells, with slight leucocytes infiltration in the epithelium and in lamina propria and T3- Fed with 30\% SLM showed significantly reduced length of villi and intestinal fold length as well with more leucocytes infiltration in the epithelium and lamina propria with focal necrotizing villi. Scale bar $=64 \mu \mathrm{m}(\mathrm{HE} \times \mathrm{40})$. Here, LP- lamina propria, GC-goblet cells, V-villi, L-leucocytes, FN-focal necrosis. leaf meal in the digestive tract. Bureau et al. (1998) reported a reduction in weight and significant intestinal damage in Chinook salmon and rainbow trout fed with saponin containing diets. Similarly, they also reported infiltration of inflammatory leucocytes cells in the lamina propria and epithelium (Krogdahl et al., 2000; Refstie et al., 2000). Healthy hepatopancreatic histoarchitecture was seen in C. carpio fed with control diets (Fig. 2). Centrally
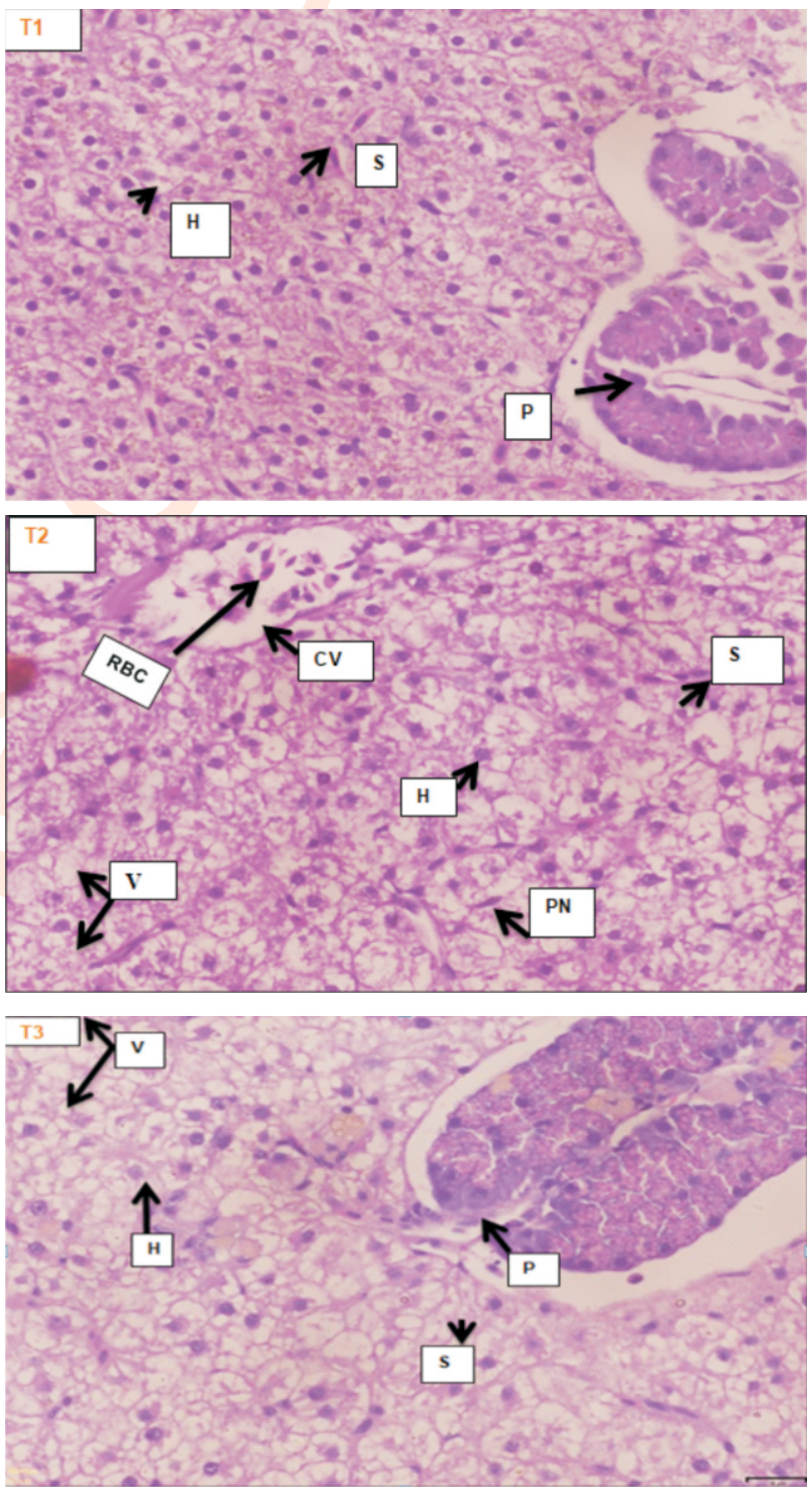

Fig. 2 : Histological section of liver of experimental fish (C. carpio) fed feed. T1-Fed with $0 \%$ SLM control group showing normal architecture of without any pathological alteration.T2- Fed with 15\% SLM shows increased number of pyknotic nuclei with slight RBC infiltration in the CV and stroma of hepatocytes, vacuolization of hepatic cells and T3- Fed with $30 \%$ SLM feed with $30 \%$ inclusion of SLM showed significantly increased vacuolization of hepatic cells, deposition of feed debris in the hepatocytes with hepatic cells degeneration. Scale bar $=64 \mu \mathrm{m}(\mathrm{HE}$ x40). Here, S- sinusoids, H- hepatocyte, PN- pyknotic nuclei, CV-central vein, V-vacuolization, P-pancreas, D- debris deposits. 
located nuclei and homogenous cytoplasm are the characteristics of hepatocytes. However, fish fed with SLM (15\% and $30 \%)$ showed atrophied nuclei with irregular staining of the cytoplasm. Hepatocyte degradation increased in fish fed with 30\% SLM. Hepatocyte degradation may be an indication of compromised health because of nutritional imbalances (Mosconi-Bac, 1990).

Further, the increased degeneration and vacuolisation of hepatocytes of higher-level SLM fed group (30\% SLM inclusion) in the present study is concordance with the study of Tan et al. (2018) in Epinephelus species fed with high lipid diets. Vacuolisation of hepatic cells may represent a degenerative change when there is fluid distension associated with toxin handling by hepatocytes (Wolf and Wheeler, 2018). The inability of $C$. carpio to adequately digest the feed incorporated with $30 \%$ SLM inclusion compared to $15 \%$ SLM included feed, and the control group may have caused higher levels of lipid deposition in hepatocytes, vacuolation and hepatocyte degradation in this fish is in agreement with the study of Hlophe (2014). The aberrant lipid accumulation in hepatocytes may be due to damage in the detoxification system of liver.

The results of this study indicate that the inclusion of Sesbania leafmeal had an apparent adverse effect on the health of Cyprinus carpio fingerlings as revealed by low survival rate in the Sesbania meal incorporated treatments. The deleterious effects are further confirmed by abnormal haematological indices and aberrated liver and intestinal histoarchitecture. This adverse effects are due to their intolerance to toxic factors present in the Sesbania leaf meal. Thus, the use of raw Sesbania leaf meal at $15 \%$ or more is not recommended in the diet of Cyprinus carpio, as a rice bran replacer. A further study is recommended by selecting lower percentage inclusion of 5 or $10 \%$ in order to just use as a minor ingredient. However, considering the potential of Sesbania leaf meal, futher studies are suggested to evaluate the use of leafmeal in Cyprinus carpio diet after detoxification using different methods.

\section{Acknowledgments}

Authors acknowledge the Director and Vice Chancellor, ICAR-Central Institute of Fisheries Education, Mumbai, India, for providing the all the required facilities for the aforesaid research work.

\section{References}

AOAC (Association of Official Analytical Chemistry): Official Methods of Analysis of the Association of Official Analytical Chemists. $15^{\text {th }}$ Edn., (Ed.: W. Horwitz), Arlington, VA: Association of Official Analytical Chemist., pp. 1298 (1995).

Ali, A., N.A. Al-Asgah, S.M. Al-Ogaily and S. Ali: Effect of feeding different levels of alfalfa meal on the growth performance and body composition of Nile tilapia (Oreochromis niloticus) fingerlings. Asi. Fisher. Sci., 16, 59-68 (2003).

Brown, D.L., D.A. Barnes, S.A. Rezende and K.C. Klasing: Yield, composition and feeding value of irrigated Sesbania sesban var.
Nubia leaves harvested at latitude $38 \mathrm{~N}$ during a mediterranean summer. Animal Feed Sci. Technol., 18, 247-255(1987).

Bairagi, A., K. Ghosh. Sarkar, S.K. Sen and A.K. Ray: Evaluation of the nutritive value of Leucaena leucocephala leaf meal, inoculated with fish intestinal bacteria Bacillus subtilis and Bacillus circulans in formulated diets for rohu, Labeo rohita (Hamilton) fingerlings. Aquac. Res., 35, 436-446 (2004).

Bell, E.A.: Non-protein amino acids in Leguminosae. In: Advances in Legume Systematics. Royal Botanical Gardens, Surrey, Gt. Britain. Vol. 2., pp. 489-499 (1978).

Bello, N.O. and G.C. Nzeh: Effects of varying levels of Moringa oleifera leaf meal diet on growth performance, hematological indices and biochemical enzymes of African catfish Clarias gariepinus (Burchell 1822). ElixirAquacult., 57, 14459-14466 (2013).

Bureau, D.P., A.M. Harris and C.Y. Cho: The effects of purified alcohol extracts from soy products on feed intake and growth of chinook salmon (Oncorhynchus tshawytscha) and rainbow trout (Oncorhynchus mykiss). Aquaculture, 161, 27-43 (1998).

Caballero, M.J., M.S. Izquierdo, E. Kjorsvik, D. Montero, J. Socorro, A.J. Fernández and G. Rosenlund: Morphological aspects of intestinal cells from gilthead sea bream (Sparus aurata) fed diets containing differentlipid sources. Aquaculture, 225, 325-340 (2003).

Da Silva, M.R., M.R.M. Natali and N.S. Hahn: Histology of the digestive tract of Satanoperca pappaterra (Osteichthyes, Cichlidae). Acta Scienti. Biolog. Sci., 34, 319-326 (2012).

Diarra, S.S., M. Koroilagilagi, S. Tamani, L. Maluhola, S. Isitolo, J. Batibasila and U. Lupea: Evaluation of cassava leaf meal protein in fish and soybean meal-based diets for young pigs. J. Agri. Rural Develop. Trop. Subtr., 118, 105-112 (2017).

Douglass, J.W. and K.W. Jane (Eds.): Schalm Veterinary Hematology. John Wiley and Sons, Blackwell Publishing Ltd.,p. 1232 (2010).

El-Sayed, A.F.M.: Alternative dietary protein sources for farmed tilapia, Oreochromis spp. Aquaculture, 179, 149-168 (1999).

Francis, G., H.P. Makkar and K. Becker: Products from little researched plants as aquaculture feed ingredients. Agrippa-FAO online Journal (2012).

Gabriel, U.U., G.N.O. Ezeriand O.O. Opabunmi: Influence of sex, source, health status and acclimation on the haematology of Clarias gariepinus (Burch, 1822). Afr. J. Biotechnol., 3, 463-467 (2004).

Gao, Y., C. Shang, M.A. Maroof, R.M. Biyashev, E.A. Grabau, P. Kwanyuen, J.W. Burton and G.R. Buss: A modified colorimetric method for phytic acid analysis in soybean. Crop Sci., 47, 17971803 (2007).

Hardy, R.W.: Utilization of plant proteins in fish diets: Effects of global demand and supplies of fishmeal. Aquaculture Res., 41, 770-776 (2010).

Hiai, S., H. Oura and T. Nakajima: Color reaction of some sapogenins and saponins with vanillin and sulfuric acid. Planta Medica, 29,116$122(1976)$

Hlophe, S.N. and N.A.G. Moyo: Evaluation of kikuyu grass and moringa leaves as protein sources in Oreochromis mossambicus diets. Afri. J. Aqu. Sci., 39, 305-312 (2014).

Hemre, G.I., H. Amlund, M. Aursand, A.M. Bakke, R.E. Olsen and E. Ringo: Criteria for Safe Use of Plant Ingredients in Diets for Aquacultured Fish. Norwegian Scientific Committee for Food Safety, Oslo, Norway., pp. 173 (2009).

Hossain, M.A., U. Focken and K. Becker: Nutritional evaluation of dhaincha (Sesbania aculeata) seeds as dietary protein source for tilapia Oreochromis niloticus. Aqua. Res., 33, 653-662 (2002). 
Hossain, M.A. and K. Becker: Nutritive value and antinutritional factors in different varieties of Sesbania seeds and their morphological fractions. Food Chemistry., 73, 421-431 (2001).

Hrubec, T.C. and J.L. Cardinale and S.A. Smith: Haematology and plasma chemistry reference intervals for cultured tilapia (Oreochromis hybrid). Veterin. Clini. Pathol., 29, 7-12 (2000).

Hansen, A.C. and G.I. Hemre: Effect of replacing fish meal and oil with plant resources in on-growing diets for Atlantic cod Gadus morhua L. Aquacult. Nutr., 19, 641-650 (2013).

Kareem S. and E. D. Sundararaj: Why Sesbania makes nutritious cattle feed. Indian Farmer, 17-20 (1967).

Kinghorn, A.D. and S.J. Smolenski:. Alkaloids of the papillionoidae. In: Advances in Legume Systematics (Eds.: R.M. Polhill and P.H. Raven). Vol. 2, Royal Botanical Gardens, Surrey, Gt. Britain (1978).

Krogdahl, A., A.M. Bakke-Mckellep, K.H. Roed and G. Baeverfjord.: Feeding Atlantic salmon Salmo salar L. soybean products: Effects on disease resistance (furunculosis), and lysozyme and lgM levels in the intestinal mucosa. Aquac. Nutr., 6, 77-84 (2000).

Kumar, V., H.P.S. Makkar and K. Becker: Dietary inclusion of detoxified Jatropha curcas kernel meal, Effects on growth performance and metabolic efficiency in common carp, Cyprinus carpio (Linnaeus). Fish Physiol. Biochem., 36, 1159-1170 (2010).

Kumar, S., N.P. Sahu, N. Shamna and A. Ranjan: Feeding higher level of de-oiled rice bran causes stress to Labeo rohita fingerlings. Aquaculture, 484, 184-190 (2018).

Mahmood, S., N. Khan, K.J. Iqbal, M. Ashraf and A. Khalique: Evaluation of water hyacinth (Eichhornia crassipes) supplemented diets on the growth, digestibility and histology of grass carp (Ctenopharyngodon idella) fingerlings. J. App. Ani. Res., 46, 24-28 (2018)

Maiti, M.K., N.P. Sahu, P. Sardar, S.N. Shahul, A.D. Deo, A. Gopan and S. Sahoo: Optimum utilization of Hygrophila spinosa leaf meal in the diet of Labeo rohita (Hamilton, 1822) fingerlings. Aquacult. Rep., 15, 100-213 (2019).

Marchetti, L., M. Capacchietti, M.G. Sabbieti, D. Accili, G. Materazzi and G. Menghi: Histology and carbohydrate histochemistry of the alimentary canal in the rainbow trout Oncorhynchus mykiss. J. Fish Biol., 68, (2006).

Makkar, H. P., P. Siddhuraju and K. Becker: Plant Secondary Metabolites. Humana Press, 393, 1-122 (2007).

Mosconi-Bac, N.: Reversibility of artificial feed-induced hepatocyte disturbances in cultured juvenile sea bass (Dicentrarchus labrax): an ultrastructural study. Aquaculture, 88, 363-370(1990).

Martınez-Llorens, S., R. Baeza-Arino, S. Nogales- Merida, M. JoverCerda and A. Tomas-Vidal: Carb seed germ meal as a partial substitute in gilthead sea bream (Sparus aurata) diets: Amino acid retention, digestibility, gut and liver histology. Aquaculture, 338-341, 124-133 (2012).

Meshram, S., A.D. Deo, S. Kumar, M. Aklakur and N.P. Sahu: Replacement of de-oiled rice bran by soaked and fermented sweet potato leaf meal: Effect on growth performance, body composition and expression of insulin like growth factor 1 in Labeo rohita (Hamilton), fingerlings. Aquacul. Res., 49, 2741-2750 (2018).

Mohapatra, S.B and A.K. Patra: Effect of partial replacement of fishmeal with duck weed (Lemna minor) feed on the growth performance of Cyprinus carpio fry. IOSR J. Agric. Veter. Sci., 4, 34-37 (2013).

Mondal, K., A. Kaviraj and P.K. Mukhopadhyay. Effects of partial replacement of fishmeal in the diet by mulberry leaf meal on growth performance and digestive enzyme activities of Indian minor carp Labeo bata. Inter. J. Aqu. Sci., 3, 72-83 (2012).

Nwankpa, K.: The histological evaluation of the effects of Moringa oleifera leaf meal inclusions on the liver and ovaries of female Oreochromis niloticus. Inter. J. Fisher. Aqu. Res., 2, 22-26 (2017).

Onim, J.F.M., P. Ochola, M. Mathuva, K. Otieno and H.A. Fitzhugh: Dry matter, nitrogen and green manure yields of Leucaena, Sesbania and pigeonpea in a cutting frequency study. In: Proceedings of $6^{\text {th }}$ KUA/SRCRSP Kenya Workshop., pp. 65-71 (1987).

Osuigwe, D.I., A.I. Obiekezie and G.C. Onuoha.: Some haematological changes in hybrid catfish (Heterobranchus longifilis x Clarias gariepinus) fed different dietary levels of raw and boiled jackbean (Canavalia ensiformis) seed meal. Afr. J. Biotechnol., 4-9 (2005).

Oyawoye E.O. and M. Ogunkunle: Physiological and biochemical effects of raw jack beans on broilers. Proceedings of Annual Conference of Nigerian Society of Animal Production, 23,141-142 (1998).

Panda, S.K., B.K. Sahu and N.C. Panda: Nutritive value of agasti (Sesbania grandiflora) leaves in Goats. Ind. J. Ani. Nutr., 5, 68-69 (1988).

Rainza-paiva M.J.T., C.M. Ishikawa, A.A. Das-Eiras and Felizardo: Haematological analysis of chara Pseudoplatystoma fasciatum in captivity responsible aquaculture in the new millennium. Nice, France. European Aquaculture Society Special Publication, 28, $590(2000)$.

Refstie, S., J. Korsoen, T. Storebakken, G. Baeverfjord, I. Lein and A.J. Roem: Differing nutritional responses to dietary soybean meal in rainbow trout (Oncorhynchus mykiss) and Atlantic salmon (Salmo salar). Aquaculture, 190, 49-63 (2000).

Roberts R.J.: Nutritional pathology of teleosts. In: Fish Pathology (Ed.: R.J. Roberts). London: Bailliere Tindall;. p. 337e62 (1989).

Shqueir, A.A., D.L. Brown and K.C. Klasing: Canavanine content and toxicity of sesbania leaf meal for growing chicks. Animal Feed Sci. Technol., 25, 137-147 (1989).

Sileshi, G., S. Sithanatham, P.L. Mafongoya, C.K. Ogol and M.R. Rao: Biology of Mesoplatys ochropetra Stal (Coleopetra: Chrysomelidae), a pest of Sesbania species, in Southern-central Africa. African Entomology, 11, 49-58 (2003).

Tan, X., Z. Sun, Q. Liu, H. Ye, Zou, C. Ye, A. Wang and H. Lin: Effects of dietary ginkgo biloba leaf extract on growth performance, plasma biochemical parameters, fish composition, immune responses, liver histology, and immune and apoptosis-related genes expression of hybrid grouper (Epinephelus lanceolatuso ${ }^{\lambda} \times$ Epinephelus fuscoguttatus ) fed high lipid diets. Fish Shellfish Immunol., 72, pp.399-409 (2018).

Varghese, T., P. Mishal, G. Gupta, M. Kumar, A.K. Pal and S. Dasgupta: Temporal changes in behavioural responses and serum metabolites of Cirrhinus mrigla exposed to acute hypoxia. J. Environ. Biol., 40, 641-647 (2019).

Wang, Y., S. Yu, Y. Wang, J. Che, L. Zhao, X. Bu and Y. Yang: Effect of replacing fish meal with soybean meal on growth, feed utilization and nitrogen and phosphorus excretion of juvenile Pseudobagrus ussuriensis. Aquacu. Res., 47, 3145-3155(2016).

Wood, I.M. and A.G. Larkens: Agronomic and phenological data for a collection of Sesbania species grown in south-east Queensland, Australia. Genetic Resources Communication, 11, (1987).

Wolf, Jeffrey. C. and J. R. Wheeler: A critical review of histopathological findings associated with endocrine and non-endocrine hepatic toxicity in fish models. Aqu. Toxicol., 197, 60-78 (2018). 